\title{
Luca Bevilacqua, Lettura di “À une passante" di Baudelaire
}

\section{Chiara Lanciano}

\section{OpenEdition}

1 Journals

\section{Edizione digitale}

URL: http://journals.openedition.org/studifrancesi/9615

DOI: 10.4000/studifrancesi.9615

ISSN: 2421-5856

\section{Editore}

Rosenberg \& Sellier

\section{Edizione cartacea}

Data di pubblicazione: 1 décembre 2007

Paginazione: 685-686

ISSN: 0039-2944

\section{Notizia bibliografica digitale}

Chiara Lanciano, «Luca Bevilacqua, Lettura di "À une passante" di Baudelaire», Studi Francesi [Online], 153 (LI | III) | 2007, online dal 30 novembre 2015, consultato il 08 janvier 2021. URL: http:// journals.openedition.org/studifrancesi/9615; DOI: https://doi.org/10.4000/studifrancesi.9615

Questo documento è stato generato automaticamente il 8 janvier 2021.

\section{(c) (i) (9)}

Studi Francesi è distribuita con Licenza Creative Commons Attribuzione - Non commerciale - Non opere derivate 4.0 Internazionale. 


\title{
Luca Bevilacqua, Lettura di “À une passante" di Baudelaire
}

\author{
Chiara Lanciano
}

\section{NOTIZIA}

LUCA BEVILACQUA, Lettura di “À une passante" di Baudelaire, «Rivista di Letterature moderne e comparate», 2006, Fasc. 2, Pisa, Pacini editore, pp. 188-204.

1 L'A. si propone di dimostrare come Baudelaire abbia genialmente rielaborato uno dei miti più abusati della letteratura, dalla lirica arcaica fino al romanzo moderno europeo, vale a dire il topos dell'“anima gemella" visto in una prospettiva di tipo platonico. À une passante non appare come la poesia di un incontro mancato ma quella di un incontro decisivo e irripetibile dove l'innamorato è destinato a "vivere in absentia la sua relazione con l'oggetto d'amore unico e insostituibile". L'A. insiste sull'altissima sfida che si è posta Baudelaire e su come abbia modernizzato il mito ambientando l'irruzione della "belle inconnue" e l'incontro fuggitivo dei due protagonisti nel contesto quotidiano ma non meno caotico della metropoli. Ci viene dimostrato come Baudelaire abbia avviato un "pathos che verte non sul tema amoroso, quanto su quello dell'irrimediabile" e del sentimento di frustrazione che da ciò deriva. 